\title{
GEDUNG PARLEMEN AUSTRALIA DARI SUDUT PANDANG KONSEP PERANCANGAN
}

\author{
Albertus Prawata \\ Jurusan Arsitektur, Fakultas Sains dan Teknologi, Bina Nusantara University \\ Jln. K.H Syahdan No 9, Palmerah, Jakarta Barat 11480 \\ albertus_prawata@binus.ac.id
}

\begin{abstract}
This paper explores the design concept of the Australian Parliament House in Canberra, Australia, which is achieved by international design competition won by Romaldo Giurgola. As a foreigner, his achievement winning the international competition for the new Australian Parliament House was remarkable. He was successfully applied the historic and symbolic values from the early Canberra master plan by Walter and Marion Griffin into his work, and he was also influenced by other architect's works such as Louis Khan.
\end{abstract}

Keywords: Australian Parliament House, design concept, international competition

\begin{abstract}
ABSTRAK
Tulisan ini akan membahas mengenai proses perancangan gedung Parlemen Australia di Canberra, Australia yang merupakan hasil sebuah kompetisi desain internasional yang dimenangkan oleh Romaldo Giurgola. Sebagai orang asing yang memiliki pengetahuan yang sangat minim mengenai Australia, keberhasilannya dapat memenangi kompetisi desain ini merupakan hal yang luar biasa. Perwujudan karyanya tidak terlepas dari pengaplikasian dan penerapan nilai-nilai histories dan simbolis yang telah diterapkan pada rancangan awal kota Canberra oleh Walter dan Marion Griffin, dan juga pengaruh pemikiran aristek lain seperti Louis Khan.
\end{abstract}

Kata kunci: Gedung Parlemen Australia, konsep perancangan, kompetisi desain internasional 


\section{PENDAHULUAN}

Pada tahun 1927 Gedung Parlemen Australia dibuka dan pemerintahan Australia pun pindah ke kota Canberra. Gedung Parlemen ini didesain dan dibangun di ibukota nasional yang baru di Canberra sebagai gedung sementara. Bangunan ini didesain untuk mengakomodasi ruang rapat besar dan ruang kantor-kantor bagi anggota staff Parlemen. Pada tahun 1947, bangunan sementara ini menjadi terlalu kecil dengan adanya penambahan jumlah anggota dan senator, dan renovasi penambahan ruang secara besar pun dilakukan.

Selama tahun 1960 dan 1970an, gedung Parlemen ini telah penuh sesak, sehingga anggota Parlemen memulai merencanakan ide-ide untuk pembangunan gedung Parlemen yang baru. Pada tahun 1978, Perdana Menteri Australia, Malcom Fraser mengumumkan sebuah kompetisi desain gedung Parlemen Australia yang akan dibangun dan siap digunakan pada tahun 1988, untuk merayakan peringatan 200 tahun penemuan benua Australia oleh Kapten James Cook (Parliamentary Education Office, 2010).

Pada bulan Juni 1980, Romaldo Giurgola, salah satu pendiri dari Mitchell/Giurgola Architects yang berdomisili di New York, Amerika, memenangkan juara pertama dari 329 peserta dari 29 negara yang mengikuti sayembara desain internasional gedung Parlemen Australia yang baru di Canberra. Kompleks Gedung Parlemen tersebut memiliki panjang 300 meter persegi dan lebar 300 meter persegi, memiliki kurang lebih dari 4700 kamar dan total luas bangunannya mencapai 250.000 meter persegi. Gedung Parlemen ini menghabiskan biaya kurang lebih sebesar 1.1 trilyun AUS dollar. Bangunan ini dibangun selama 7 tahun dan dibuka pada tanggal 9 Mei 1988 oleh Ratu Elizabeth II (Dunkerley, 2008).

\section{PEMBAHASAN}

\section{Rencana Awal Kota Canberra 1912}

Proudfoot (1993) menyatakan bahwa desain awal untuk kota Canberra, Australia yang dikembangkan oleh Marion dan Walter Griffin pada tahun 1912 tidak dapat dipahami tanpa mengenali bahwa aksis darat (tanah) menghubungkan gunung Ainslie dengan tugu peringatan perang (War Memorial), Jalan Anzac, sistem danau, segitiga parlemen dan bukit Capital, menerus sampai dengan Bimberi Peak, salah satu gunung tertinggi yang berjarak 25 kilometer kearah selatan pusat kota.

Selanjutnya Proudfoot (1993) menjelaskan bahwa Bimberi Peak ditujukan sebagai titik (terminal) akhir, bukan bukit Capital, dari aksis darat (tanah). Hal ini ditunjukan baik pada gambargambar dan laporan awal oleh Griffin. Aksis utara-selatan dan aksis air yang membentang dari timurbarat, membentuk sebuah tanda salib (cross) yang merupakan sebuah kontruksi monumental dari jaman terdahulu seperti pada jaman Konstantine di kota Roma. Dasar ide awal design Griffin berasal dari aturan religi masa lampau dan pengertian mereka terhadap geomancy, suatu ilmu pengetahuan masa lampau yang menempatkan manusia berhamoni dengan bumi. Canberra memiliki persamaan dan hubungan terhadap prisip-prisip arsitektur dan perencanaan masa lampau seperti pada jaman Stonehenge, kuil di Mesir sampai dengan Piramida. Dari semuanya itu, Canberra berbagi sebuah bentuk geometri yang sakral dilandasi oleh Vesica, sebuah gabungan yang terbentuk dari dua lingkaran yang menggambarkan realita spiritual dan fenomena material. Hasil komposisi dari Vesica adalah lingkaran, persegi, segitiga, jajaran genjang dan polygon beraturan, yang saling berhubungan, dan dengan demikian menentukan struktur geometri dari kerangka arsitektur yang jelas terlihat sekarang yang diperkuat oleh desain Gedung Parlemen yang baru. 


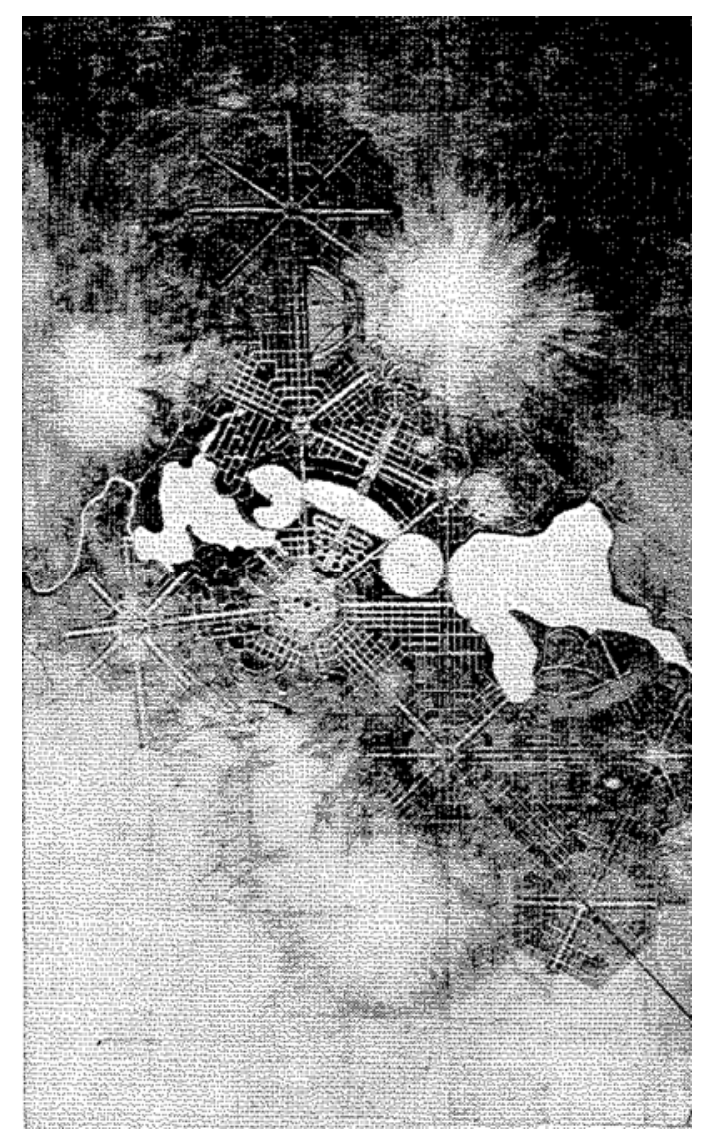

Gambar 1 Desain Rencana awal kota Canberra

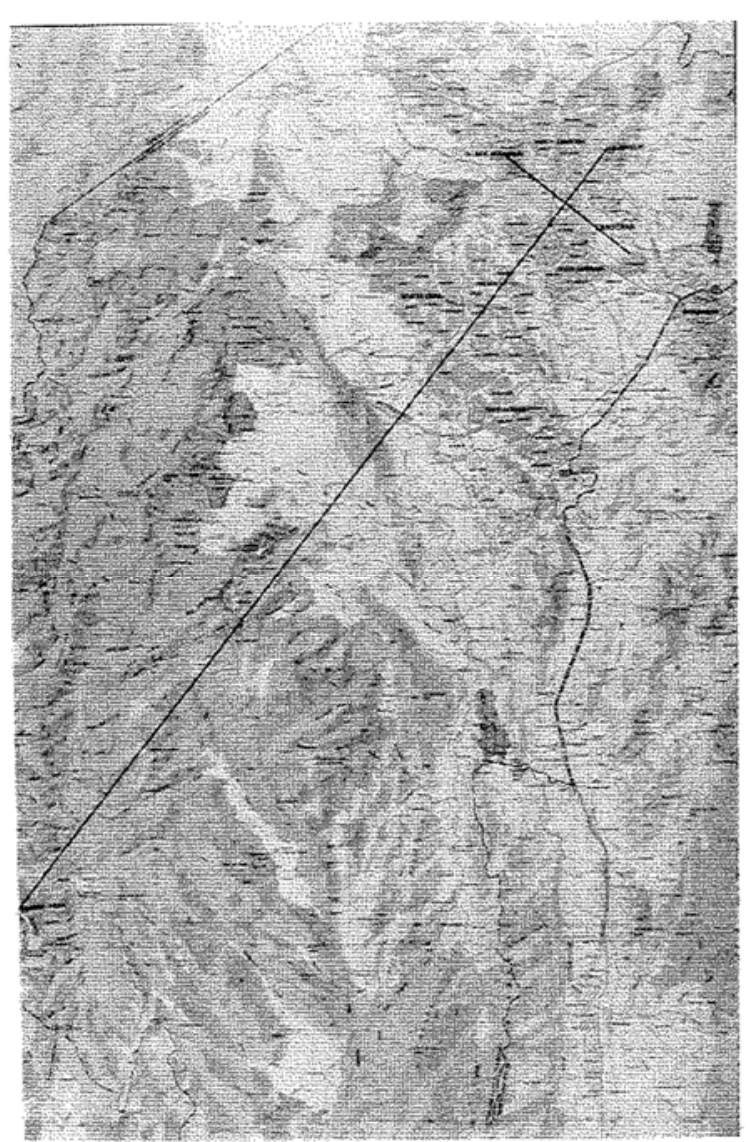

Gambar 2 Aksis darat (tanah) dan air ; Mt. Ainslie Bimberi Peak dan Black Mountain - Lake Peak

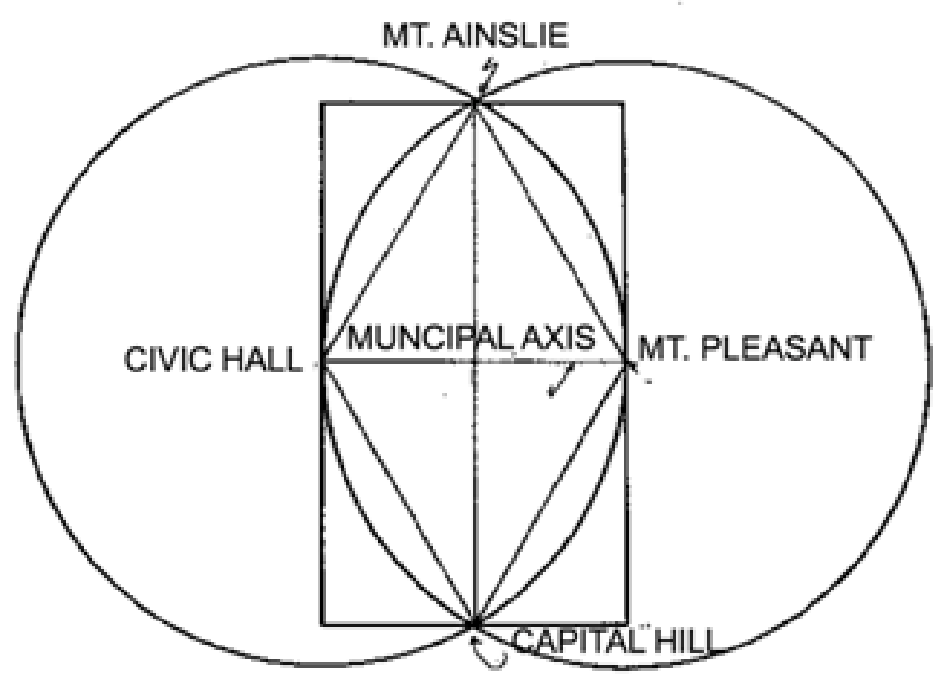

Gambar 3 Bentuk Vesica yang berhubungan dengan Canberra 


\section{Romaldo Giurgola}

Giurgola lahir di Roma pada tahun 1920, ia menyelesaikan pendidikan arsitekturnya di Rome University pada tahun 1949. Dia menerima gelar master arsitektur dari universitas Columbia University, dan telah menjadi mitra di biro Philadelphia Mitchell/Giurgola Arsitek sejak tahun 1958. Beliau menjabat sebagai profesor di University of Pennsylvania dan Columbia University. Giurgola kemudian menjadi ketua departemen arsitektur di Columbia University pada tahun 1966. Ia dianugerahi Medali Emas AIA (American Institute of Architects) pada tahun 1982 (Archinform, 2010).

Stephen Frith (2010) menjelaskan, sebelum pembukaan Gedung Parlemen Australia yang baru pada tahun 1988, Romaldo Giurgola sudah banyak terlibat dalam beberapa level pertukanan kultur budaya, mediasi dan memberikan roh pada karyanya. Giurgola juga menekankan pemikiran-pemikiran utama yang selalu konstan hadir pada karya-karyanya yaitu: definisi sebuah tempat melalui tahapan ruang yang teratur sebagai satu kesatuan bagian yang utuh, bahasa ruang dipahami sebagai suatu definisi internal atau eksternal dalam perumusan suatu fungsi, pemikiran arsitektur yang sudah ada dapat dijadikan sebagai dasar yang penting dalam arsitektur, perkembangan estetika pada arsitektur didasari oleh aksesbilitas pada bangunan, kejelasan dan kekuatan untuk menjelaskan arti dan hubungannya.

Pembahasan mengenai gedung Parlemen Australia ini selanjutnya akan dibahas berdasarkan ke empat nilai yang secara konstan selalu menjadi pertimbangan Giurgola dalam mendesain karyakaryanya.



Gambar 4 Romaldo Giurgola

\section{Gedung Parlemen Australia}

\section{Definisi Sebuah Tempat}

Lokasi gedung Parlemen yang baru terletak pada bagian berbukit (bukit Capital), bagian dari rancangan kota oleh Walter Burley Griffin pada tahun 1912. Lokasi gedung Parlemen yang baru ini secara visual merupakan pusat dari suatu aksis (sumbu). Konsep dasar desain dari gedung Parlemen Australia yang baru ini adalah menciptakan dan mempertahankan rasa kepemilikan pada suatu tempat dan lokasi (the sense of a place), yang sudah terbentuk dan melalui referensi-referensi yang sudah ada sebelumnya. Kedua dinding yang melengkung mengikuti profil bukit telah menciptakan suatu ruang rekreasi bagi publik. Dinding ini juga mendefinisikan aksis (sumbu) tanah (Utara-Selatan) dan 
memisahkan kedua kubu oposisi pemerintahan yang ada di Australia, yaitu kubu perwakilan (The House of Representatives) di sisi timur, dan kubu senat (Senate) di sisi barat.



Aerial plan of Australia's Parliament House

Gambar 5 Pembagian zoning fungsi gedung Parlemen Australia Sumber: Parliamentary Education Office - Australia's Parliament House

Menangkap semangat dan karakter suatu tempat (site) juga merupakan bagian utama dalam pemikiran desain Giurgola pada rancangan gedung Parlemen Australia ini terlihat sangat jelas. Bentuk bangunan menciptakan suatu keharmonisan terhadap lingkungannya yang menjelaskan pentingnya lokasi dan tempat yang ditentukan oleh sumbu tanah yang menghubungkan bukit Capital sampai dengan gunung Ainslie. Bangunan ini seakan-akan tertanam di dalam tanah, dan fasad eksterior gedung Parlemen ini secara visual seakan-akan menyatu dengan bangunan Parlemen yang lama apabila kita melihatnya dari kejauhan. Hal ini menciptakan suatu visual yang sangat menarik, dimana terdapat susunan layer antara kedua gedung Parlemen Australia yang lama dan baru terhadap landscape sekitarnya. Gambar yang menunjukan susunan (layer) antara bangunan Parlemen yang lama dan baru menggambarkan sebuah proses berlanjutan dari pemerintahan Australia. Ide ini berasal dari konsep awal ; kontinuitas supremasi visual aksis tanah yang diterapkan oleh Griffin.

Giurgola juga telah berhasil menciptakan tampak bangunan yang sederhana, yang dengan baik dapat tertangkap dari kejauhan dan berhasil menyatu dengan lingkungannya. Bangunan ini juga menekankan pentingnya Tugu Perang Australia (Australian War Memorial). Tugu Perang ini merupakan suatu simbol penghormatan bagi para warganya yang telah terlibat perang dalam membela Australia di perang dunia 1 dan 2. Dengan berada pada aksis yang sama (aksis tanah), Pemerintah Australia dalam hal ini digambarkan melalui gedung Parlemen secara simbolis memberikan penghargaan kepada mereka yang telah berkorban bagi Australia dalam perang. 


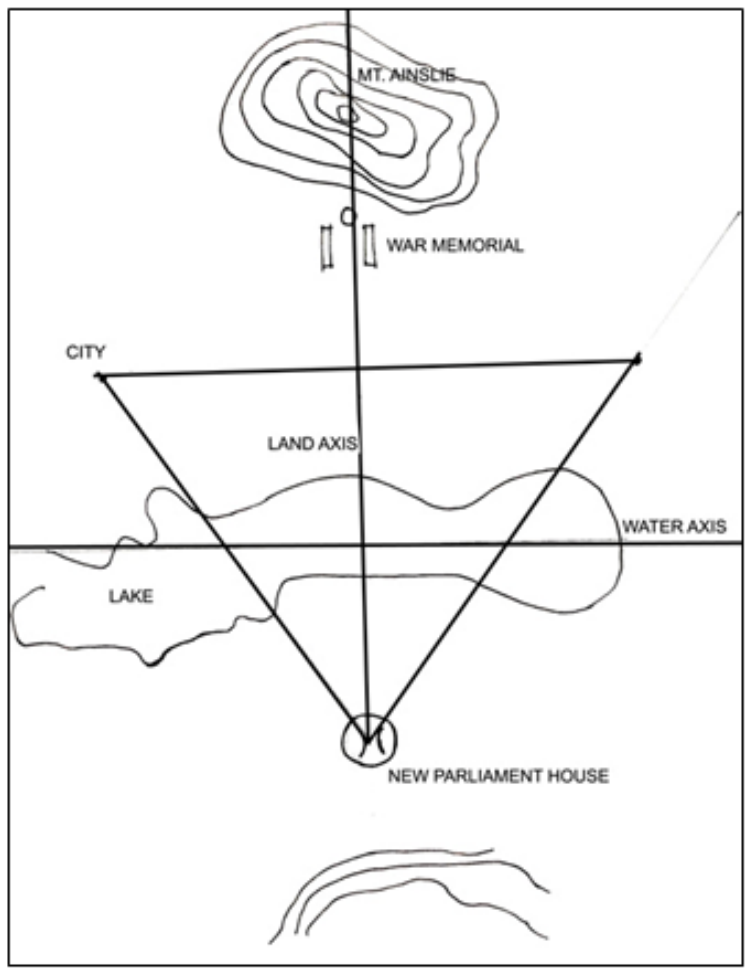

Gambar 6 Sketsa diagram posisi letak gedung Parlemen Australia yang membentuk suatu pusat aksis terhadap tanah dan air. Terlihat posisinya terhadap Tugu Perang, letak kota, dan bagian penting lainnya.

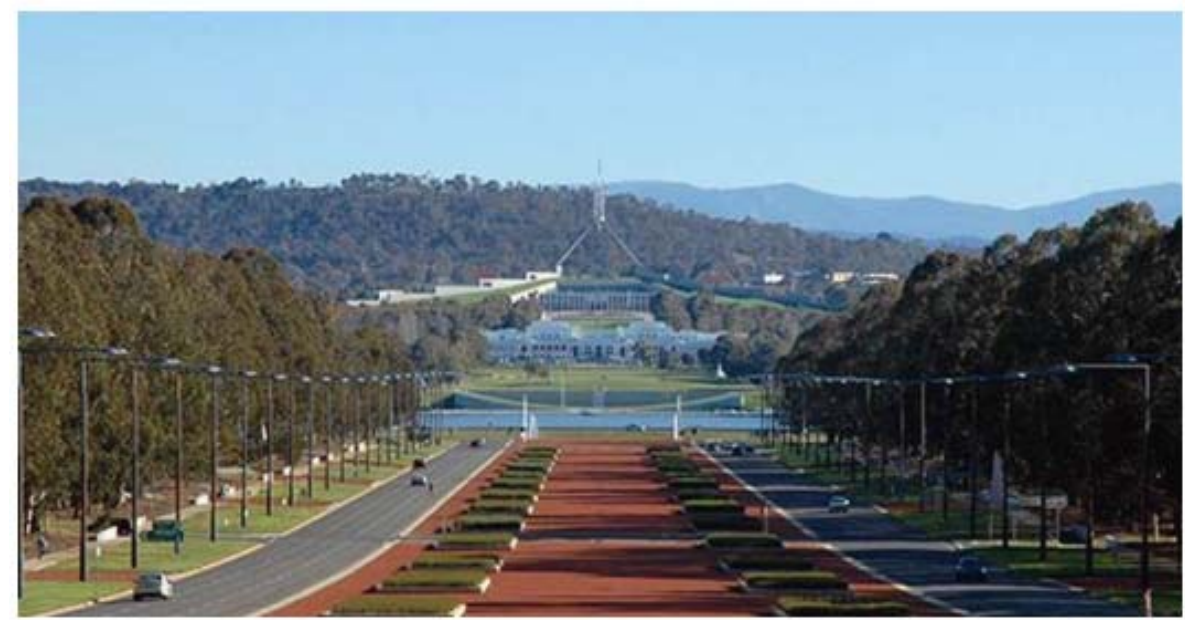

Gambar 7 Gedung Parlemen Australia yang baru dan lama seakan-akan menyatu.

\section{Bahasa Ruang (Interior)}

Aksis Utara-Selatan pada lokasi (site) juga terdefinisikan di dalam bangunan gedung Parlemen dalam bentuk beberapa tahapan ruang. Ruang yang pertama, ruang penerima (foyer) yang berfungsi sebagai ruang publik. Desain foyer ini dihiasi oleh pola lantai yang sangat detail dengan kolomkolomnya. Setelah foyer, terdapat ruang serba guna yang besar (the great hall). Di ruangan ini terdapat pencahayaan dari langit yang diletakan di tengah-tengah ruang. Dinding dan lantainya menggunakan material dari bahan kayu. Ruangan berikutnya adalah Member's Hall yang terdiri dari 3 lantai. Ruang ini merupakan pusat dari bangunan Parlemen Australia, tempat dimana aksis Utara-Selatan dan aksis 
Timur-Barat pada bagunan bertemu. Dari ruangan ini kita dapat pergi ke sisi Timur bangunan yang merupakan ruang berkumpulnya anggota perwakilan (The House of Representatives). Sedangkan pada sisi Barat Member's Hall terdapat ruang berkumpulnya anggota Senat (Senate).

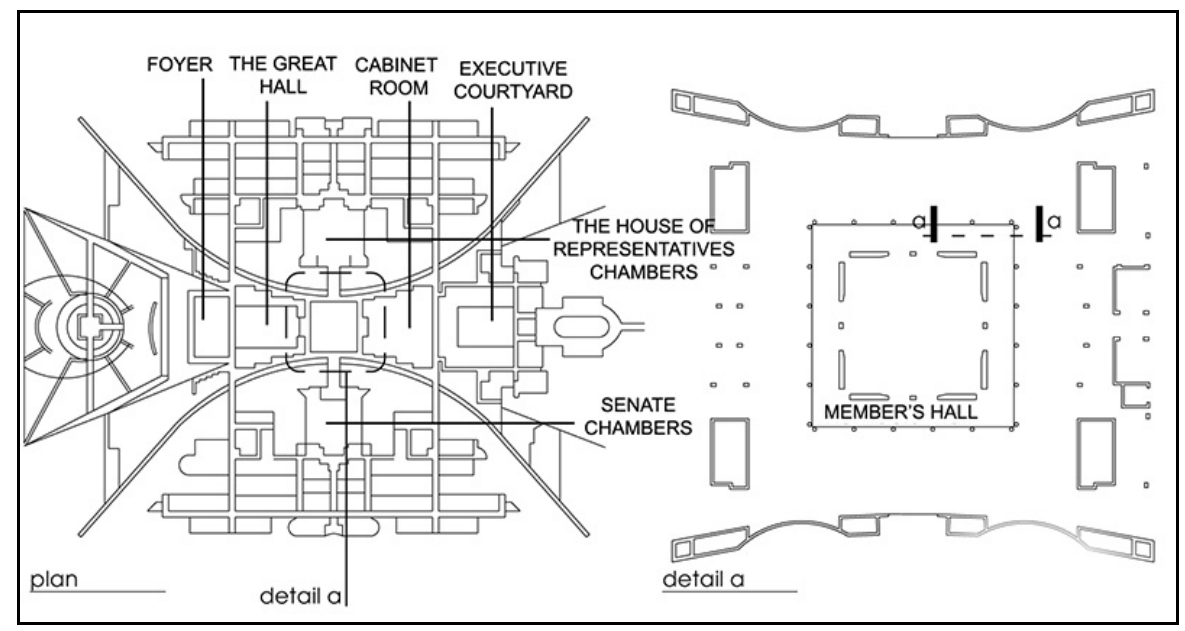

Gambar 8 Diagram denah gedung Parlemen Australia



Gambar 9: Foyer Gedung Parlemen Australia

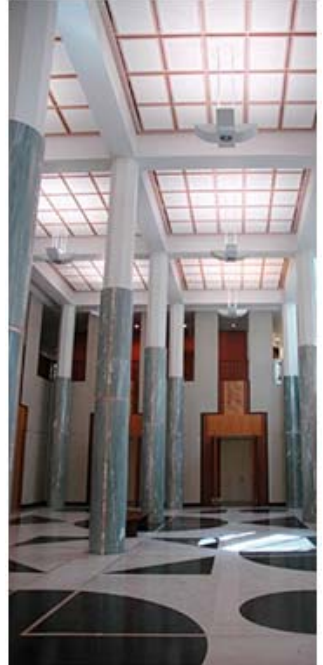

Gambar 10: The Member's Hall

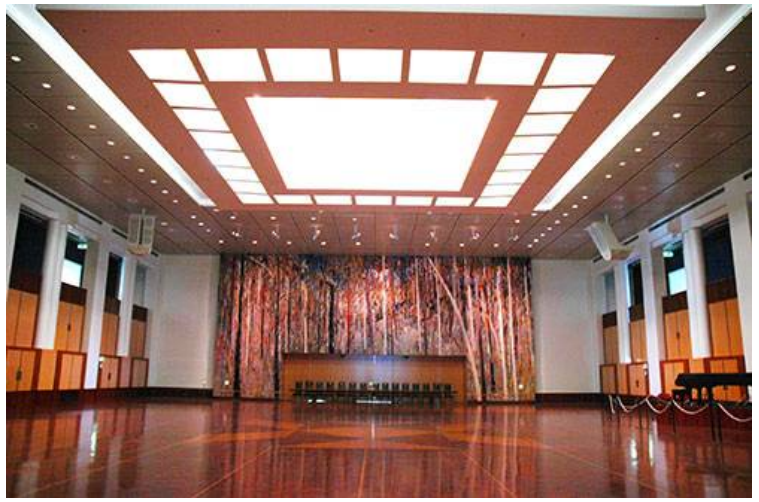

Gambar 11 The Great Hall 


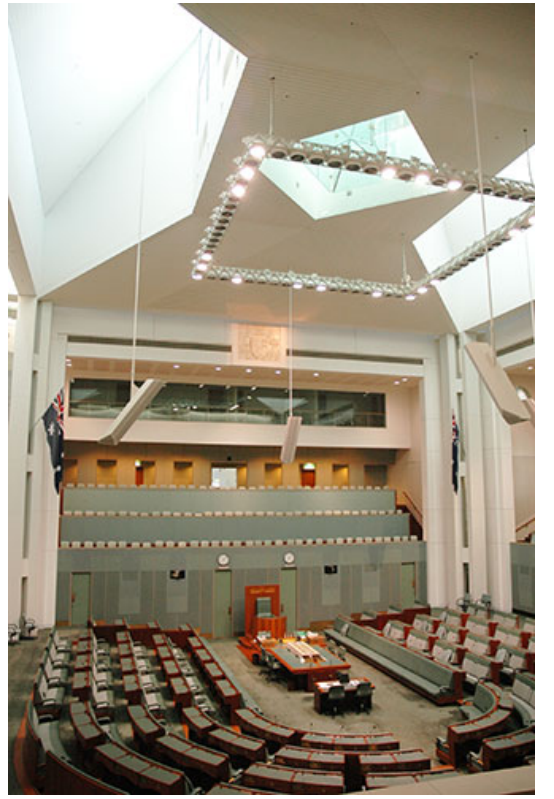

Gambar 12: The House of Representatives chamber



Gambar 13: The Senate chamber

\section{Pemikiran Arsitektur yang Sudah Ada (Louis Khan)}

Menurut Beier (2006), Selama tahun 1960-1970an, Giurgola mempublikasikan beberapa artikel di jurnal, majalah arsitektur dan juga sebuah buku mengenai karya-karya Louis Khan. Karyakarya publikasi ini menunjukan pengaruh Louis Khan dalam karya-karya arsitektur Giurgola, seperti pentingnya suatu konteks dan tempat dalam mendesain. Louis Kahn, yang dikenal sebagai salah satu arsitek besar dari abad ke-20, telah menghasilkan karya-karya penting sepanjang karirnya, dan ia juga telah membuat beberapa gambar yang menunjukkan ide-ide tentang bagaimana dia mendesain dan menciptakan karya arsitekturnya. Kahn membuat suatu gambar yang menunjukkan ide tentang bagaimana sebuah ruang arsitektur dapat dibentuk untuk membuat suatu kesepakatan dan percakapan antara pengguna bangunan dan juga terhadap lingkungan sekitarnya. Gambarnya yang disebut "the room" menunjukkan bahwa pengguna sedang mengalami suatu percakapan terhadap ruang yang digunakan dan juga lingkungan sekitar. Hal ini menunjukkan bahwa arsitektur yang baik harus mendorong pengguna untuk bisa menciptakan suasana ruang yang hidup.



Gambar 14 Sketsa Louis Khan - “Architecture comes from the making of a room” 
Pengaruh pemikiran Louis Khan, mengenai adanya komunikasi yang baik antara pengguna bangunan, ruangan dan juga lingkungannya terlihat dalam ruang yang Giurgola desain, terutama di Member's Hall. Ruangan ini memiliki kualitas yang sama terhadap karya Khan yaitu Exeter library, dimana terdapat ruang bersama di tengah bangunan dan terdapat penerangan alami pada atapnya (skylight).

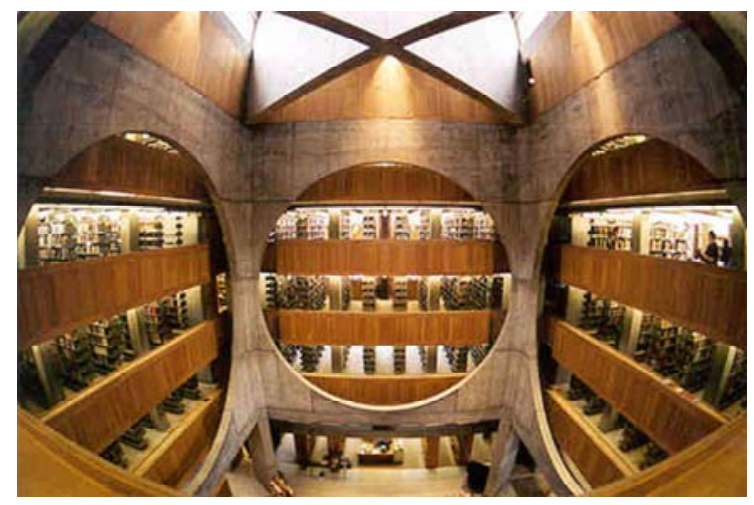

Gambar 15 Louis Khan Exeter Library

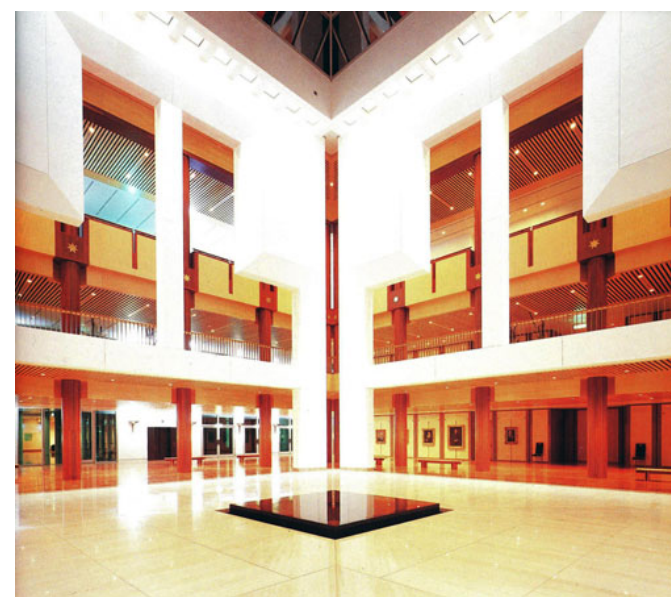

Gambar 16 Romaldo Giurgola Member's Hall Australian Parliament House

Ruang Member's Hall merupakan ruang yang sangat penting di bangunan Parlemen Australia. Ruangan ini terdiri dari 3 lantai, dan juga terdapat air mancur di tengah ruangan dan mendapatkan pencahayaan alami dari atap. Di ruang ini, setiap lantai ditujukan untuk pengguna yang berbeda. Lantai pertama ditujukan untuk para politisi, lantai ke dua untuk publik dan lantai ke tiga untuk kalangan wartawan dan media. Pembagian level (lantai) pengguna tersebut juga dapat terlihat pada sisi luar bangunan (eksterior), dimana kita dapat melihat bukaan jendela pada jalan, koridor menuju ruang (chamber) partai politik (The House of Representatives atau The Senate). Di ruang Member's Hall, merupakan suatu ruang dimana publik, politisi dan media terhubung melalui koneksi visual. Faktor keselamatan, menjadi faktor utama kenapa pada ruang ini ketiga kelompok pengguna tidak disatukan pada satu lantai. Tetapi, hirarki penggunanya menciptakan sebuah kesepakatan terhadap pengguna ruang melalu koneksi visual tersebut meskipun mereka berada pada tingkat yang berbeda. Pemilihan material pada Member's Hall juga menjadikan ruang ini menjadi sangat spesial. Penggunaan material dari marmer dan juga kayu serta penambahan pecahayaan alami yang masuk pada ruang ini menjadikan ruang ini memiliki kesan yang hangat. Membuat semua orang merasa menjadi satu.

\section{Estetika Arsitektur}

Penggunaan karya-karya seni di gedung Parlemen Australia ini merupakan nilai yang tidak dilupakan oleh Giurgola dalam perancangannya, terutama dalam mendesain sebuah karya publik (Clark, 2006). Arsitek, artis dan juga pekerja konstruksi memiliki peran masing-masing dalam mendesain sebuah bagunan publik. Di ruang Member's Hall, kita dapat melihat presisi yang sangat indah penggunaan material kayu dan marmer. Kita juga dapat melihat bintang-bintang berwarna kuning yang terdapat diatas kolom yang tertempel dengan indah pada material kayu. Hal ini menggambarkan jumlah Negara bagian dan wilayah di Australia. Salah satu contoh karya seni yang cukup menonjol juga terdapat pada area publik lainnya di the Great Hall (Gambar 11).

Giurgola juga mencoba merepresentasi desain konsep awal Griffin's mengenai simbol, demokrasi Australia dan keanekaragaman yang ada. Simbol demokrasi Australia pada bangunan Parlemen ini diwujudkan dengan bentuk atap yang menyerupai bukit dengan adanya taman atap (roof 
garden) yang bisa diakses oleh publik. Hal ini menunjukan gambaran demokrasi Australia di mana masyarakat Australia secara hirarki berada di atas wakil yang dipilih mereka.

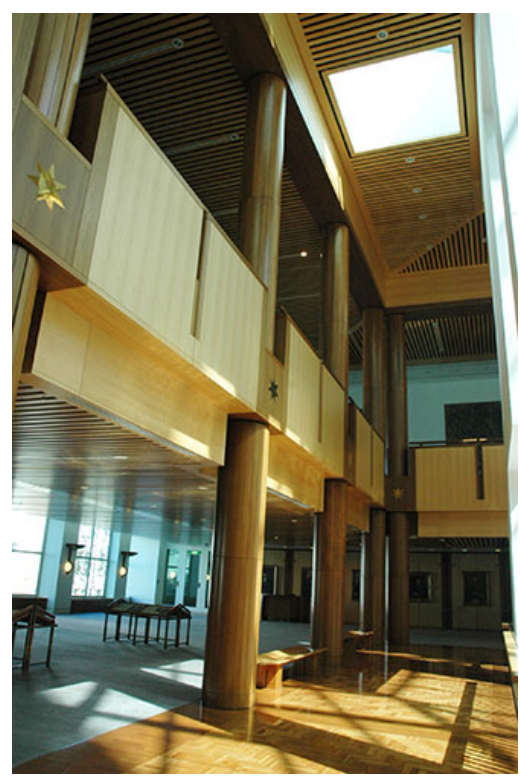

Gambar 16 Penggunaan material kayu yang indah dengan penambahan nilai simbolik dalam bentuk bintang yang terdapat diatas kolom-kolom di Member's Hall.

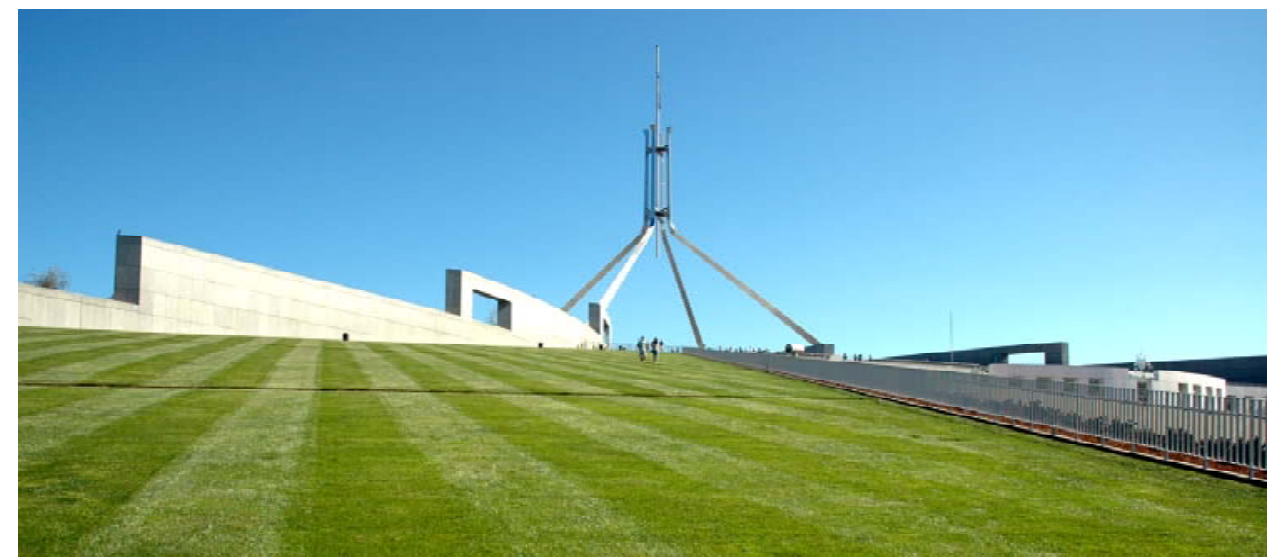

Gambar 17 Roof garden pada gedung Parlemen Australia

\section{PENUTUP}

Dari pembahasan yang telah dilakukan, dapat disimpulkan bahwa rancangan gedung Parlemen Australia merupakan suatu proses yang berkelanjutan. Dimulai dari rancangan awal kota Canberra oleh Walter dan Marion Griffin di tahun 1912 sampai dengan pembangunan Gedung Parlemen Australia itu sendiri oleh Romaldo Giurgola yang mulai digunakan pada tahun 1988. Dalam perancangan gedung Parlemen Australia ini, Giurgola secara konstan menerapkan nilai-nilai penting yang selalu ia terapkan dalam merancang karya-karya lainnya seperti yang telah ia sebutkan pada bukunya (Mitchell \& Giurgola, 1983). 
Salah satu faktor yang selalu ia jadikan konsep pemikiran dalam merancang karyanya yang terlihat kuat dalam rancangan gedung Parlemen Australian ini adalah faktor definisi akan sebuah tempat sebagai suatu rancangan yang utuh. Dengan adanya proses awal yang ingin menjadikan Canberra sebagai tempat pusat pemerintahan yang besar sejak adanya kompetisi desain pada tahun 1912, Giurgola dengan baik memahami hal ini, sehingga proses berkelanjutan serta nilai-nilai sejarah dan simbolis pada lokasi ini tidak ia hilangkan, tetapi ia pertahankan dan diperjelas oleh bentukbentuk rancangannya. Faktor tempat yang erat kaitannya dengan sejarah merupakan salah satu faktor yang sangat kuat dalam konsep perancangan gedung Parlemen Australia, suatu hal yang tentu akan menjadi pertimbangan dalam suatu konsep perancangan terutama untuk bangunan pemerintahan yang menjadi simbol suatu negara. Gedung Parlemen Australia yang sudah berumur 22 tahun sejak diresmikan dari tahun 1988, menjadi sebuah contoh yang baik sebagai gedung lambang pemerintahan. Gedung ini dirancang untuk bertahan selama 200 tahun (Lennon, 2008), hal ini menunjukan pentingnya suatu kontinuitas dan ketahanan suatu struktur lambang Negara, suatu konsep yang mempertegas definisi sebuah tempat dan kontinuitas pada desain Giurgola pada gedung Parlemen Australia. Romaldo Giurgola sebagai perancang utama gedung Parlemen Australia sangat tegas dan konstan mempraktekan pemikiran-pemikiran dan nilai-nilai arsitektural dalam karyanya. Rancangan gedung Parlemen Australia ini tentunya menjadi salah satu karya terbesar baginya, dan hal tersebut pun telah membuat suatu perubahan besar, dimana ia akhirnya memutuskan untuk pindah dan menjadi warga Negara Australia. Gedung Parlemen ini juga memberikan suatu perubahan bagi Australia dan Canberra secara khusus. Kota Canberra menjadi kota yang penuh nilai sejarah dan simbol bagi Australia, dan dengan kehadiran gedung pemerintahan yang baru telah mempertegas nilai-nilai tersebut dengan seuatu bentukan dan bahasa arsitektur yang baik.

\section{DAFTAR PUSTAKA}

Archinform. (2010). Romaldo Giurgola, diakses 1 Juni 2010 dari http://eng.archinform.net/arch/4372.htm

Beier, B. R. (2006). Preserving the Work of Mitchell/Giurgola Associates. Graduate Program in Historic Preservation (Thesis; Historic preservation). University of Pennsylvania.

Clark, J. 2006. Romaldo Giurgola. Architecture Australia, issue: January/February 2006.

Dunkerley, S. (May 8, 2008). Parliament House to mark $20^{\text {th }}$ birthday. Sydney Morning Herald.

Frith S. (2010). Past and Present Exchanges in the Work in Australia of Romaldo Giurgola. Interspaces Abstracts and Biographies. Diakses 1 juni 2010 dari http://www.culturecommunication.unimelb.edu.au/interspaces\%20.html

Lennon, T. (May 9, 2008). Building Our National House. The Daily Telegraph.

Mitchell, E. B., \& Giurgola, R. (1983). Mitchell/Giurgola Architects. New York: Rizzoli.

Parliementary Education Office. (2010). Australia's Parliament House, diakses 1 Juni 2010 dari http://www.peo.gov.au/students/cl/aph.html

Proudfoot, P. (1993). Ancient Cosmological Symbolism in the Initial Canberra Plan. Fabrications: The Journal of the Society of Architectural Historians, Australia and New Zealand, 4: 139169. 